\title{
S100B and homocysteine in the acute alcohol withdrawal syndrome
}

\author{
Dirk Wedekind • Karolin Neumann • \\ Peter Falkai • Berend Malchow • Kirsten Rita Engel • \\ Katja Jamrozinski · Ursula Havemann-Reinecke
}

Received: 20 April 2010/Accepted: 18 June 2010/Published online: 1 July 2010

(C) The Author(s) 2010. This article is published with open access at Springerlink.com

\begin{abstract}
Elevations of serum homocysteine levels are a consistent finding in alcohol addiction. Serum S100B levels are altered in different neuropsychiatric disorders but not well investigated in alcohol withdrawal syndromes. Because of the close connection of S100B to ACTH and glutamate secretion that both are involved in neurodegeneration and symptoms of alcoholism the relationship of S100B and homocysteine to acute withdrawal variables has been examined. A total of 22 male and 9 female inpatients (mean age $46.9 \pm 9.7$ years) with an ICD-10 diagnosis of alcohol addiction without relevant affective comorbidity were examined on admission and after 24,48 , and $120 \mathrm{~h}$ during withdrawal. S100B and homocysteine levels in serum were collected, and severity of withdrawal symptoms (AWS-scale), applied withdrawal medication, initial serum ethanol levels and duration of addiction were recorded. Serum S100B and homocysteine levels declined significantly $(P<.05)$ over time. Both levels declined with withdrawal syndrome severity. Females showed a trend to a more intense
\end{abstract}

D. Wedekind $(\varangle) \cdot$ K. Neumann $\cdot$ P. Falkai · B. Malchow

K. R. Engel · U. Havemann-Reinecke

Department of Psychiatry and Psychotherapy,

University of Goettingen, von-Siebold-Strasse 5,

37075 Goettingen, Germany

e-mail: dwedeki1@gwdg.de

K. Jamrozinski

Department of Psychosomatic Medicine and Psychotherapy,

University of Goettingen, von-Siebold-Strasse 5,

37075 Goettingen, Germany

P. Falkai · U. Havemann-Reinecke

CMPB (Center for Molecular Physiology of the Brain),

Goettingen, Germany decline in serum S100B levels compared to males at day $5(P=.06)$. Homocysteine levels displayed a negative relationship to applied amount of clomethiazole $(P<.05)$ and correlated with age of onset of addiction. No withdrawal seizures were recorded during the trial. As it is known for homocysteine, S100B revealed to decline rapidly over withdrawal treatment in alcoholism. This effect is more pronounced in female patients. S100B could be of relevance in the neurobiology of alcohol withdrawal syndromes. It may be indirectly related to the level of stress level or glutamatergic activity during alcohol withdrawal.

Keywords Alcohol addiction - Homocysteine · S100B · Withdrawal

$\begin{array}{ll}\text { Abbreviations } \\ \text { ACTH } & \text { Adrenocorticotropin } \\ \text { AWS-scale } & \text { Acute withdrawal-scale } \\ \text { ELISA } & \text { Enzyme-linked-immuno-sorbent-assay } \\ \text { GABA } & \text { Gamma-amino-butyric acid } \\ \text { HPA } & \text { Hypothalamo-pituitary-adrenomedullary } \\ & \text { (axis) } \\ \text { HRP } & \text { Horseradish-peroxydase } \\ \text { ICD-10 } & \text { International classification of diseases, 10th } \\ & \text { revision } \\ \text { kDA } & \text { kilo-Dalton } \\ \text { MALT } & \text { Munich alcoholism test } \\ \text { MRI } & \text { Magnetic resonance imaging } \\ \text { NMDA } & N \text {-methyl-D-aspartate } \\ \text { RAGE } & \text { Receptor for advanced glycation } \\ & \text { end products } \\ \text { SAH } & \text { S-adenosyl-L-homocysteine } \\ \text { WHO } & \text { World Health Organization }\end{array}$




\section{Introduction}

Alcohol addiction and alcohol withdrawal syndromes have been related to numerous biologic markers indicating syndrome severity or detrimental effects. The GABAergic system undergoes distinct adaptive processes over alcohol addiction going in line with receptor down-regulation and altered sensitivity [1]. During withdrawal, reduced GABA agonistic effects coincide with an increase in glutamatergic neurotransmission [2]. A compensatory up-regulation of glutamatergic NMDA receptors over chronic alcohol intake has been described [3].

Elevations of homocysteine and its main metabolite homocysteic acid in serum are a consistent finding in alcohol addiction [4-6] and withdrawal [7-9]. Due to excitatory NMDA and glutamatergic effects and reduction of inhibitory GABAergic drive by lack of ethanol, homocysteine has been related to excitatory somatic and psychic withdrawal symptoms, risk of withdrawal-related seizures, and excitotoxic neurodegenerative phenomena [10-12].

S100 proteins are small, acidic proteins of 10-12 kDa. $\mathrm{S} 100 \mathrm{~B}$ is a calcium-binding astroglial peptide which has trophic or deleterious effects on neural cells in a dosedependent manner [13]. Mild S100B levels have been associated with stimulatory effects on neuronal growth, sprouting, and plasticity (e.g. concerning the central nervous serotonergic system and a diminution of glutamatedriven cytotoxicity) $[14,15]$. High levels of S100B, on the other hand activate early immediate genes (c-fos) [13] and long-term high levels of S100B by increasing intracellular calcium levels have been related to neurotoxicity and degeneration at different sites [16]. Besides astrocytes and other brain tissues [17], S100B is secreted by the folliculostellate cells in the anterior pituitary after stimulation of the stress axis and ACTH secretion [18]. Simultaneously, glutamate synthetase is secreted from folliculostellate cells. S100B has the highest density of intracellular binding sites (receptor for advanced glycation end products: RAGE) in neurons and glial cells of the hippocampus. Certain regions of this structure have been reported to be highly vulnerable to neurotoxic effects by S100B or glucocorticoids [13]. Such effects are thought to be glutamate driven.

Elevated levels of serum or cerebrospinal fluid S100B have been reported for psychiatric disorders such as schizophrenia [19-21] or affective disorders [22-26] which often co-occur with alcohol addiction [27, 28]. The role of S100B in psychiatric disorders is still not very clear. Taken together, it can be assumed that psychopathological alterations in different syndromes represent a fairly unspecific condition deriving from a general stress-level or increased glutamatergic drive leading to conditions of restricted declarative memory or emotional processing abilities. There seems to be a crucial role of the central nervous serotonergic system in this respect. On the one hand, Serotonin 1a receptor stimulation increases S100B levels, on the other hand S100B has been considered to improve serotonergic neuron regeneration [29] most probably in mild concentrations.

Data on S100B in addictive disorders, in particular in alcohol dependence is still scarce. Animal data demonstrated that S100B reduces ethanol-induced apoptosis [30]. One clinical study measure S100B in patients undergoing inpatient withdrawal treatment assessed a significant elevation of S100B at admission compared to discharge after approximately $4-5$ weeks. However, this effect was only found in patients with severe addiction and previously high average alcohol consumption [31].

An association between homocysteine and S100B levels over the alcohol withdrawal syndrome can be hypothesized. Homocysteine levels correspond with NMDA and glutamate activity in the withdrawal period. Neurotoxic effects in certain brain areas correspond with dramatically raised S100B levels. These are facilitated by glutamate activity. However, mild S100B increases may diminish glutamatedriven neurotoxicity. This study was performed in order to further elucidate the role of S100B in alcohol withdrawal syndromes and to correlate respective levels with withdrawal syndrome severity and the well-known alterations in serum homocysteine over the withdrawal period. Furthermore, it was of interest if values showed a connection to addiction severity, duration of addictive drinking or gender.

\section{Methods}

The study was approved by the local ethics committee

Thirty-one inpatients undergoing a qualified alcohol withdrawal treatment at the department of psychiatry and psychotherapy of the University of Goettingen were included into this study during October 2007 and August 2008. Patients were males or females 18-70 years of age hospitalized for voluntary qualified detoxification treatment and suffering from alcohol addiction according to ICD-10 criteria [32]. Patients with any psychotic symptoms, clinically relevant major depression, polyvalent substance use (except for nicotine), incapacitating organic brain disorder, risk factors for hyperhomocysteinaemia, or regular psychotropic drug treatment in the 4 weeks before admission were excluded from participation. Subjects with relevant language problems or patients unable to give free informed consent were not included.

Patients were recruited within the first $24 \mathrm{~h}$ after admission to the clinic. After checking for in and exclusion criteria and having given informed consent a serum sample for the assessment of S100B, homocysteine, and alcohol 
concentration was drawn. Further serum samples were drawn after 24, 48, and $120 \mathrm{~h}$. On the latter 3 occasions, the AWS scale [33] in order to assess withdrawal syndrome severity was applied. Blood pressure and heart rate was recorded on each of the 4 occasions, and the amount of applied withdrawal-related medication during the past $24 \mathrm{~h}$ was recorded. Blood ethanol concentration was controlled $24 \mathrm{~h}$ after the first sampling. In the end of the study (120 h after the first blood sample), participants completed a severity scale for alcohol addiction (MALT [34]). Sociodemographic data and information about duration of alcohol addiction/age of onset of alcohol addiction was collected.

S100B was measured by ELISA according to Leite [35]. Fifty-microliter serum samples were analyzed using Clone SH-B1 (Sigma Chemical Co.) as a capture antibody and a polyclonal detecting antibody (Dako). Homocysteine was measured by ELISA according the method described by Frantzen [36]. Twenty-five-microliter serum samples were analyzed using anti-SHA-antibody (Abbot Labs.) and HRP-conjugated antibody (Dako).

\section{Treatment during study}

All participants received a qualified detoxification treatment with uniform supplementation of vitamins (B1, B6, B12) and potassium (taken orally). Qualified detoxification treatment comprised psychosocial treatment (including motivational training), physiotherapy and prescription of withdrawal related medication following cardiovascular monitoring.

\section{Statistical analysis}

Statistical analyses were performed by using SPSS (version 17.0). Pearson correlations were computed for age and gender related to S100B and homocysteine at the respective time-points. Pearson correlations for S100B/homocysteine and syndrome severity according to the AWS score was calculated as well as for age of addiction onset and duration of alcohol addiction and for applied clomethiazole medication.

Repeated measures analysis (ANOVA, SPSS method Bonferroni) was performed for S100B, homocysteine, and AWS scores over the study period. $P$ values below .05 were considered significant.

\section{Results}

Study population

Of the included 31 subjects ( 22 men, 9 women), 30 subjects completed the trial. Subjects were between 28 and
68 years old (mean $46.9 \pm 9.7$ ). No significant age differences between men $(45.8 \pm 7.3)$ and women $(49.4 \pm$ 12.0) were detected. Mean duration of alcohol addiction was $13.4 \pm 8.7$ years (range 1.5-33) mean age of onset of addiction was at the age of $33.5 \pm 10.5$ years (range 19-60 years). Mean daily consumption of alcohol prior to admission was $262 \pm 124 \mathrm{~g} /$ day (range 95-631 g/day). Mean blood alcohol concentration at the first sampling time-point was $1.41 \pm 1.09$ per mille (range 0-3.5 per mille). MALT-scores had a mean of $15.5 \pm 4.7$.

\section{Serum S100B and homocysteine}

A comparable course was detected for S100B levels in serum with a linear and significant decline over the investigational period. Mean baseline values, however, were still in the normal range $(74 \pm 8 \mathrm{ng} / \mathrm{l})$ and declined to $51 \pm 6 \mathrm{ng} / \mathrm{l}$ over the following $120 \mathrm{~h}(F=5.88 ; P<.05$; see Table 1). There was no significant correlation between age and homocysteine levels, neither was there any significant correlation between age and S100B levels.

On average, subjects displayed mildly elevated homocysteine serum-levels at baseline $(19.3 \pm 2.2 \mu \mathrm{mol} / \mathrm{l})$ that declined significantly over the following $120 \mathrm{~h}(F=10.71$; $P<.05$; see Table 1). There was no significant correlation between age and homocysteine levels.

As an effect of gender, females displayed more rapidly declining S100B values; however, this was just a statistical trend $(r=0.35 ; P=.064$; at $120 \mathrm{~h}$; women vs. men).

A correlation between age of onset of alcohol addiction and homocysteine levels could be detected. This correlation was most evident from values after $48 \mathrm{~h}(r=0.43$; $P<.05)$ and was slightly less after $24(P=.076)$ and $120 \mathrm{~h}(P=.052)$.

Another remarkable finding were the lower homocysteine levels after $24 \mathrm{~h}$ in patients the more clomethiazole they received $(r=-0.64 ; P<.05)$. This effect could not be demonstrated for the subjects receiving diazepam.

Table 1 Mean S100B and homocysteine serum levels over the investigational period incl. 95\% confidence interval

\begin{tabular}{|c|c|c|c|c|}
\hline & $0 \mathrm{~h}$ & $24 \mathrm{~h}$ & $48 \mathrm{~h}$ & $120 \mathrm{~h}$ \\
\hline \multicolumn{5}{|c|}{ Homocysteine $\mu \mathrm{mol} / 1$} \\
\hline Mean \pm SD & $19.3 \pm 2.2$ & $17 \pm 1.4$ & $14.8 \pm 1.1$ & $13.6 \pm 1$ \\
\hline $95 \% \mathrm{CI}$ & $14.9-23.8$ & $14.3-19.8$ & $12.6-17.1$ & $11.5-15.6$ \\
\hline LOS vs. $0 \mathrm{~h}$ & & & & $P<.05$ \\
\hline \multicolumn{5}{|l|}{ S100B ng/l } \\
\hline Mean \pm SD & $74 \pm 8$ & $61 \pm 9$ & $54 \pm 6$ & $51 \pm 6$ \\
\hline $95 \% \mathrm{CI}$ & $58-90$ & $43-78$ & $41-67$ & $38-63$ \\
\hline LOS vs. $0 \mathrm{~h}$ & & & & $P<.05$ \\
\hline
\end{tabular}

$S D$ standard deviation, $C I$ confidence interval, LOS level of significance 
Correlations between S100B, homocysteine, and AWS-scores

Despite the linear decline of values for all three categories, no significant direct correlations could be detected between these variables.

\section{Withdrawal syndrome severity}

No withdrawal related seizures nor any withdrawal delirium was recorded in the sample over the study period.

\section{AWS-scale}

Scores on the AWS scale declined significantly $(F=4.81$; $P<.05)$ over time with highest scores after $24 \mathrm{~h}$ $(5.97 \pm 2.97)$. Scores after $48 \mathrm{~h}$ were $4.63 \pm 1.62$ and $3.43 \pm 0.96$ after $120 \mathrm{~h}$. There were no significant differences in AWS-scores between men and women at any assessment point.

\section{Blood pressure and heart rate}

Blood pressure showed a slight but non-significant decline between 24 and $120 \mathrm{~h}(145.5 \pm 5.2 \mathrm{mmHg}$ for systolic and $88.4 \pm 8.5$ for diastolic values at $24 \mathrm{~h}$ vs. $132 \pm 16.2$ for systolic and $84.3 \pm 9.4$ at $120 \mathrm{~h}$ ).

Heart rate declined non-significantly over time $(94 \pm 12.8$ at $24 \mathrm{~h}$ vs. $85 \pm 13$ at $120 \mathrm{~h})$.

\section{Applied withdrawal medication}

Clomethiazole $(n=13)$, diazepam $(n=12)$, phenobarbital $(n=3)$, and carbamazepine $n=11)$ were used in the population. Phenobarbital was used for patients with mild withdrawal syndromes who had adverse medication effects from diazepam or clomethiazole during previous withdrawal treatments.

Number of individuals treated with clomethiazole decreased from 13 at time $0 \mathrm{~h}$ to 2 at $120 \mathrm{~h}$. Applied amount of clomethiazole decreased from a mean of $7.4 \pm 4.2$ capsules (192 $\mathrm{mg}$ each) at baseline to $1.5 \pm 0.5$ capsules at $120 \mathrm{~h}$. Mean intake of clomethiazole capsules did not differ between men (3.9 \pm 3.0 capsules/day) and women (3.5 \pm 2.4 capsules/day). Three subjects did not need any withdrawal-related medication.

\section{Discussion}

In support of our hypothesis, a significant decline of serum S100B levels over time could be detected, although average levels were in the normal range (compared to values from the literature). However, 95\% confidence interval values support the likelihood of higher S100B levels at the beginning of withdrawal treatment. Although no direct correlation with withdrawal severity according to the AWS could be demonstrated, all 3 variables decline in a linear fashion. S100B appears to be of certain relevance in the biology of alcohol withdrawal syndromes, maybe giving indirect reference to stress level or glutamatergic activity. Probably these alterations are not particularly specific for alcohol withdrawal syndromes. In major depression correlations of S100B and symptom, severity could be demonstrated and also in schizophrenia. Yet, these entities represent syndromes connected to cognitive or emotional impairment with distinct hippocampal impairment (e.g. [37]). It could be speculated that S100B as well as homocysteine are related to effects on e.g. hippocampal areas that cause unspecific symptoms that occur in different psychiatric disorders. Yet, actions of S100B are concentration dependent. Those higher levels at baseline compared to endpoint in this population are likely to be in the neuroprotective and trophic range of $\mathrm{S} 100 \mathrm{~B}$, and probably represent a protective, counter-regulatory mechanism against the harmful effects of hyperhomo-cysteinemia and associated glutamate-mediated neurotoxicity.

Just slightly missing the level of significance $(P=.064$; $r=0.35$ ) women tended to have lower level of serum $\mathrm{S} 100 \mathrm{~B}$ at endpoint. This is a finding that in a way contradicts the results by Yang [26] who found higher cerebrospinal fluid S100B in depressed women compared to men. However, women had no significantly different withdrawal severity scores according to the AWS scale. Neither were women significantly different with regard to age or in the amount of applied withdrawal medication such as clomethiazole. Therefore, despite the small $\mathrm{n}$, this may reflect a gender effect. It could be hypothesized that neuroprotective effects of S100B are expressed to a lower degree in female alcohol addicted subjects. Age as well as blood ethanol levels at admission were comparable in men and women. One contributing factor, a lower average consumption of alcohol prior to withdrawal in women compared to men, cannot be excluded and would be in line with the findings of Liappas et al. [31].

As expected, homocysteine serum values declined significantly from a moderately elevated level over the 120-h investigational period in this population undergoing qualified alcohol detoxification treatment.

One interesting issue deriving from our data is the significant inverse relationship between serum homocysteine levels and clomethiazole intake. This effect was not immediately observable but after 1 day of intake which could represent an adaptive GABA mediated effect. In contrast to this, S100B levels were not moderated by clomethiazole. Possibly, clomethiazole treatment may need to 
be considered as relevant in the interpretation of homocysteine levels in alcohol addiction.

Correlations between homocysteine and age have been consistently reported, and as a trend can be adapted from our data. Also amount of alcohol intake prior to admission has been found to be associated with higher serum homocysteine. This may correspond with higher stress levels and a higher risk for cardiovascular diseases. However, as suggested by some authors (e.g. [38]), we could not find gender specific effects. Animal studies have indicated circadian variations of serum homocysteine and age-related effects [39]. However, we could not detect any relationship to age of subjects. Circadian shifts in homocysteine levels were controlled by comparable time frames for all subjects. The fact that our data revealed a positive correlation between homocysteine serum levels and age of onset of alcohol addiction appears surprising. It implies an association between a shorter duration of the disorder with higher serum levels of excitatory homocysteine. Alimentary reasons for this effect due to reduced intake of methyl-groupdonators [40] can be hypothesized.

Nevertheless, the results presented here should not be over-interpreted due to several limitations of the study. The rather small study population was probably too heterogeneous. Less than a third $(n=9)$ of the subjects were women, and the recruited subjects did not necessarily have to have positive blood alcohol concentrations at inclusion. Five patients in this population in fact were admitted to the clinic without blood alcohol, whereas several previous studies (e.g. [7, 8, 41] did not include patients with negative blood alcohol due to a certain determination of homocysteine levels by the degree of blood ethanol levels [7].

According to our hypothesis of a diagnosis unspecific phenomenon of elevated S100B in parallel with elevated stress markers, we must admit that no statement at all on HPA function can be made from our study. Compared to another open-label study on S100B in alcohol withdrawal by Liappas [31] who measured S100B levels in alcoholaddicted subjects undergoing withdrawal treatment at admission and at discharge (after 4-5 weeks), this appears to be a clear limitation of that study. The investigational period in this trial was very much shorter. It was comparable with other investigations on homocysteine in alcohol withdrawal (e.g. [7, 8] stressing the relevance of the acute detoxification period over the first days of treatment.

Finally, although serum S100B measurements are a valid measure, we cannot entirely exclude alterations of blood-brain-barrier functioning in alcohol-addicted subjects [42] as the cause of these slightly higher initial S100B serum levels. One recent publication [43] identified the body-mass-index (BMI) as a contributing factor to serum S100B levels, which we did not take into account.

\section{Conclusions}

Serum S100B levels show a decline over a 5-day period similar to homocysteine in alcohol-addicted subjects undergoing acute inpatient alcohol withdrawal. Due to the well-known concentration-dependent trophic or neurotoxic effects of S100B, the demonstrated data may represent an adaptive, counter-regulatory function of S100B protecting sensitive neuronal brain structures against deleterious effects mediated by homocysteine or glutamate. Further investigations on larger populations taking HPA-function into account appear useful. S100B serum levels and their relationship to homocysteine in non-abstinent alcoholics could be of interest due to the often postulated NMDA balance of excitatory homocysteine and inhibitory, GABAergic ethanol effects.

Open Access This article is distributed under the terms of the Creative Commons Attribution Noncommercial License which permits any noncommercial use, distribution, and reproduction in any medium, provided the original author(s) and source are credited.

\section{References}

1. Mhatre MC, Pena G, Sieghart W, Ticku MK (1993) Antibodies specific for GABAA receptor alpha subunits reveal that chronic alcohol treatment down-regulates alpha-subunit-expression in rat brain regions. J Neurochem 61(5):1620-1625

2. Tsai GE, Ragan P, Chang R, Chen S, Linnoila VM, Coyle JT (1998) Increased glutamatergic neurotransmission and oxidative stress after alcohol withdrawal. Am J Psychiatry 155:726-732

3. Kril JJ, Halliday GM (1998) Brain shrinkage in alcoholics: a decade on and what have we learned? Prog Neurobiol 58:381387

4. Cravo ML, Gloria LM, Selhub J, Nadeau MR, Camilo ME, Resende MP, Cardoso JN, Leitao CN, Mira FC (1996) Hyperhomocysteinemia in chronic alcoholism: correlation with folate, vitamin B-12, and vitamin B-6 status. Am J Clin Nutr 63(2): 220-224

5. Halsted CH (2001) Lifestyle effects on homocysteine and an alcohol paradox. Am J Clin Nutr 73(3):501-502

6. Hultberg B, Berglund M, Andersson A, Frank A (1993) Elevated plasma homocysteine in alcoholics. Alcohol Clin Exp Res 17:687-689

7. Bleich S, Degner D, Wiltfang J, Maler JM, Niedmann P, Cohrs S, Mangholz A, Porzig J, Sprung R, Rüther E, Kornhuber J (2000) Elevated homocysteine levels in alcohol withdrawal. Alcohol Alcohol 35:351-354

8. Bleich S, Sperling W, Wiltfang J, Maler JM, Kornhuber J (2003) Excitatory neurotransmission in alcoholism. Fortschr Neurol Psychiatr 71(suppl 1):36-44

9. Bleich S, Hillemacher T (2009) Homocysteine, alcoholism and its molecular networks. Pharmacopsychiatry 42(suppl 1):102-109

10. Bleich S, Degner D, Bandelow B, von Ahsen N, Rüther E, Kornhuber J (2000) Plasma homocysteine is a predictor of alcohol withdrawal seizures. Neuroreport 11(12):2749-2752

11. Bleich S, Bandelow B, Javaheripour K, Müller A, Degner D, Wilhelm J, Havemann-Reinecke U, Sperling W, Rüther E, Kornhuber J (2003) Hyperhomocysteinaemia as a new risk factor 
for brain shrinkage in patients with alcoholism. Neurosci Lett 335:179-182

12. Lipton SA, Kim WK, Choi YB, Kumar S, D`Emilia DM, Rayudu PV, Arnelle DR, Stamler JS (1997) Neuro-toxicity associated with dual actions of homocysteine at the N-methyl-D-aspartate receptor. Proc Natl Acad Sci USA 94:5923-5928

13. Hu J, Castets F, Guevara JL, Van Eldik LJ (1996) S100B stimulates inducible nitric oxide synthase activity and mRNA levels in rat cortical astrocytes. J Biol Chemistry 271(5):2543-2547

14. Barger SW, Van Eldik LJ, Mattson MP (1995) S100B protects hippocampal neurons from damage induced by glucose deprivation. Brain Res 677:167-170

15. Whitacker-Azmitia PM, Clarke C, Azmitia EC (1993) Localization of 5HT1a receptors to astroglial cells in adult rats: Implications for neuronal-glial interactions and psychoactive drug mechanisms of action. Synapse 14:201-205

16. Barger SW, Van Eldik LJ (1992) S100B stimulates calcium influxes in glial and neuronal cells. J Biol Chemistry 267(14): 9689-9694

17. Steiner J, Bernstein HG, Bielau H, Berndt A, Brisch R, Mawrin C, Keilhoff G, Bogerts B (2007) Evidence for a wide extra-astrocytic distribution of S100B in human brain. BMC Neurosci 8:2

18. Shirasawa N, Yamanouchi H (1999) Glucocorticoids induce glutamine synthetase in folliculostelate cells of rat pituitary glands in vivo and in vitro. J Anat 194:567-577

19. Ling SH, Tang YL, Jiang F, Wiste A, Guo SS, Weng YZ, Yang TS (2007) Plasma S-100B protein in Chinese patients with schizophrenia:comparison with healthy controls and effect of antipsychotics treatment. J Psychiatr Res 41(1-2):36-42

20. Schroeter ML, Abdul-Khaliq H, Krebs M, Diefenbacher A, Blasig IE (2009) Neuron-specific enolase is unaltered whereas $\mathrm{S} 100 \mathrm{~B}$ is elevated in serum of patients with schizophrenia-original research and meta analysis. Psychiatry Res 167:66-72

21. Wiesmann M, Wandinger KP, Missler U, Eckhoff D, Rothermundt M, Arolt V, Kirchner H (1999) Elevated plasma levels of S100B protein in schizophrenic patients. Biol Psychiatry 45:1508-1511

22. Andreazza AC, Cassini C, Rosa AR (2007) Serum S100B and antioxidant enzymes in bipolar patients. J Psychiatr Res 41: 523-529

23. Arolt V, Petres M, Erfurth A, Wiesmann M, Missler U, Rudolf S, Kirchner H, Rothermundt M (2003) S100B and response to treatment in major depression: a pilot study. Eur Neuropsychopharmacol 13(4):235-239

24. Rothermundt M, Arolt V, Wiesmann M, Missler U, Peters M, Rudolf S, Kirchner H (2001) S100B is increased in melancholic but not in non-melancholic major depression. J Affect Disord 66:89-93

25. Schroeter ML, Abdul-Khaliq H, Diefenbacher A, Blasig IE (2002) S100B is increased in mood disorders and may be reduced by antidepressive treatment. Neuroreport 13(13):1675-1678

26. Yang K, Xie GR, Hu YQ, Mao FQ, Su LY (2008) The effects of gender and number of depressive episodes on serum S100B levels in patients with major depression. J Neural Transm 115:1687-1694

27. Soyka M, Albus M, Immler B, Kathmann N, Hippius H (2001) Psychopathology in dual diagnosis and non-addicted schizophrenics-are there differences? Eur Arch Psychiatry Clin Neurosci 251(5):232-238

28. Mann K, Hintz T, Jung M (2004) Does psychiatric comorbidity in alcohol-dependent patients affect treatment outcome? Eur Arch Psychiatry Clin Neurosci 254(3):172-181
29. Grabe HJ, Ahrens N, Rose HJ, Kessler C, Freyberger HJ (2001) Neurotrophic factor S100 beta in major depression. Neuropsychobiol 44(2):88-90

30. Druse MJ, Gillespie RA, Tajuddin NF, Rich M (2007) S100Bmediated protection against the proapoptotic effects of ethanol on fetal rhombencephalic neurons. Brain Res 1150:46-54

31. Liappas I, Tvavellass EO, Kariyannis C, Piperi C, Schulpis C, Papassotiriou I, Sodatos CR (2006) Effect of alcohol detoxification on serum S100B levels of alcohol-dependent individuals. In Vivo 20(5):675-680

32. World Health Organisation (WHO) (1991) Tenth revision of the international classification of diseases, chapter $\mathrm{V}(\mathrm{F})$ : mental and behavioural disorders (including disorders of psychological development). Clinical descriptions and diagnostic guidelines. World Health Organisation, Geneva

33. Wetterling T, Kanitz RD, Besters B, Fischer D, Zerfass B, John U, Spranger H, Driessen M (1997) A new rating scale for the assessment of the alcohol withdrawal syndrome. Alcohol Alcohol 32(6):753-760

34. Feuerlein W (1979) Early recognition and diagnosis of alcoholism. Bull Schw Akad Wiss 35(1-3):173-186

35. Leite MC, Galland F, Brolese G, Guerra MC, Bortolotto JW, Freitas R, Almeida LM, Gottfried C, Goncalves CA (2008) A simple, sensitive and widely applicable ELISA for S100B: Methodological features of the measurement of this glial protein. J Neurosci Methods 169(1):93-99

36. Frantzen F, Faaren AL, Alfheim I, Nordhei AK (1998) Enzyme conversion immunoassay for determining total homocysteine in plasma or serum. Clin Chem 44(2):311-316

37. Meisenzahl EM, Seifert D, Bottlender R, Teipel S, Zetzsche T, Jäger M, Koutsouleris N, Schmitt G, Scheuerecker J, Burgermeister B, Hampel H, Rupprecht T, Born C, Reiser M, Möller HJ, Frodl T (2010) Differences in hippocampal volume between major depression and schizophrenia: a comparative neuroimaging study. Eur Arch Psychiatry Clin Neurosci 260(2):127-137

38. Brandao LC, Hachul H, Bittencourt LR, Baracat EC, Tufik S, D'Almeida V (2009) Effects of isoflavone on oxidative stress parameters and homocysteine in postmenopausal women complaining of insomnia. Biol Res 42:281-287

39. Martins PJ, Galdieri LC, Souza FG, Andersen ML, BeneditoSilva AA, Tufik S, D‘Almeida V (2005) Physiological variation in plasma total homocysteine concentration in rats. Life Sci 76(22):2621-2629

40. Lever M, Sizeland PCM, Frampton CM, Chambers ST (2004) Short and long-term variation of plasma glycine betaine concentrations in humans. Clin Biochem 37(3):84-90

41. Bleich S, Degner D, Sperling W, Bönsch D, Thürauf N, Kornhuber J (2004) Homocysteine as a neurotoxin in chronic alcoholism. Prog Neuropsychopharmacol Biol Psychiatry 28:453-464

42. Kornhuber J, Kaiserauer CH, Kornhuber AW, Kornhuber ME (1987) Alcohol consumption and blood-cerebrospinal fluid barrier dysfunction in man. Neurosci Lett 79:218-222

43. Ehrlich S, Salbach-Andrae H, Weiss D, Burghardt R, Goldhahn K, Craciun EM, Franke L, Uebelhack R, Klapp BF, Lehmkuhl U (2008) S100B in underweight and weight-recovered patients with anorexia nervosa. Psychoneuroendocrinology 3(6):782-788 